\title{
9 \\ The Rule of Law in International Law Today
}

\author{
STÉPHANE BEAULAC
}

\section{INTRODUCTION}

$\mathrm{T}$

The 'RULE OF law' is undoubtedly one of the most powerful expressions in the modern world. ${ }^{1}$ In a sense, it has become an activity in itself, a mental-social phenomenon which exists within human consciousness and acts independently within physical social reality, ${ }^{2}$ like a pat on the back or a slap in the face. Or, to put it differently, through the cognitive process of the human mind, the language of the rule of law has not only represented reality, but has also played a leading role in the creation and transformation of reality; accordingly, it has contributed to the modelling of the shared consciousness of society, ${ }^{3}$ including that of international society.

While the various ideas associated with the expression are undoubtedly very old ${ }^{4}$ - going as far back as Plato and Aristotle-the emergence of the rule of law as a potent discursive tool within political and legal circles has been relatively recent. ${ }^{5}$ The phrase itself was actually coined by nineteenth-century British author Albert Venn Dicey, ${ }^{6}$ in his masterpiece

\footnotetext{
${ }^{1}$ On the role of language, especially in the context of international law, see S Beaulac, The Power of Language in the Making of International Law-The Word Sovereignty in Bodin and Vattel and the Myth of Westphalia (Leiden: Martinus Nijhoff, 2004).

2 This borrows from the speech-act theory of JL Austin, How to do Things with Words (Oxford: Clarendon Press, 1962).

${ }^{3}$ On the creation and transformation of human-constructed reality through the use of language, see L Wittgenstein, Tractatus Logico-Philosophicus (London: Routledge, 1961); and L Wittgenstein, Philosophical Investigations (Oxford: Blackwell, 1958).

${ }^{4}$ See JN Shklar, 'Political Theory and the Rule of Law' in AC Hutchinson and P Monahan (eds), The Rule of Law: Ideal or Ideology (Toronto: Carswell, 1987) p 1.

${ }^{5}$ See J Rose, 'The Rule of Law in the Western World: An Overview' (2004) 35 Journal of Social Philosophy 457 at 457.

6 See HW Arendt, "The Origins of Dicey's Concept of the "Rule of Law"' (1957) 31 Australian Law Journal 117.
} 
Introduction to the Study of the Law of the Constitution. ${ }^{7}$ It is from this point in time that this chapter takes up the rule of law, originally developed at the domestic level, with a view to seeing how an externalised version of the concept may be projected onto the international plane.

Writing at the turn of the millennium, Paul Johnson referred to the establishment of the rule of law within nation states as 'the most important political development of the second millennium'; he ventured to predict, in his optimistic conclusion, that the development of a global or international rule of law 'is likely to be among the achievements of the third millennium'. ${ }^{8}$ Adopting a more prudent tone, in his book On the Rule of Law, Brian Tamanaha argued that the first project, the rule of law on a national level, 'remains a work in progress', while the second one, the rule of law internationally, 'has only just begun'. ${ }^{9}$ But it has indeed begun, and not only at the normative level, but also at the functional level and, to a lesser degree, at the institutional level.

The following discussion starts, in Section II, with a survey of how the rule of law has developed in domestic law, focusing on the contributions of legal (as well as political) scholars. Section III then sets out the main goal of the chapter, which is to externalise the core values of the rule of law onto the international plane in order to examine how they can be found in the essential features of the international legal system. Two variables are examined for the purpose of this study, namely the version of the rule of law (limited to a formal level) and the definition of international law (limited to its traditional understanding). The conclusion then briefly revisits the theme of language as social power in relation to the international rule of law.

\section{THE RULE OF LAW DEFINED}

Although admittedly a convenient shortcut, starting our discussion of the meaning of the rule of law with its modern articulation by Albert Venn Dicey has little risk of running into strong opposition. ${ }^{10}$ His conception is well known and largely accepted; it has also been analysed and criticised from a variety of angles, ${ }^{11}$ thus adding to the credibility of his formulation.

\footnotetext{
7 AV Dicey, Introduction to the Study of the Law of the Constitution (London: Macmillan, 1885).

8 P Johnson, 'Laying Down the Law: Britain and America Led the Way in Establishing Legal Regimes Based on Universal Principles', Wall Street Journal, 10 March 1999, A22.

${ }_{9}$ BZ Tamanaha, On the Rule of Law: History, Politics, Theory (Cambridge: Cambridge University Press, 2004) p 127.

${ }^{10}$ See NB Reynolds, 'Grounding the Rule of Law' (1989) 2 Ratio Juris 1.

11 See I Stewart, 'Men of Class: Aristotle, Montesquieu and Dicey on "Separation of Powers" and "The Rule of Law"' (2004) 4 Macquarie Law Journal 187; and BJ Hibbitts, 'The Politics of Principle: Albert Venn Dicey and the Rule of Law' (1994) 23 Anglo-American Law Review 1.
} 


\section{A. Dicey's Theory of the Rule of Law}

Dicey wrote that the rule of law had 'three meanings, or may be regarded from three different points of view'. ${ }^{12}$ First, the expression means 'the absolute supremacy or predominance of regular law as opposed to the influence of arbitrary power ${ }^{\prime 13}$ He further opined:

We mean, in the first place, that no man is punishable or can be lawfully made to suffer in body or goods except for a distinct breach of law established in the ordinary legal manner before the ordinary courts of the land. In this sense the rule of law is contrasted with every system of government based on the exercise by persons in authority of wide, arbitrary, or discretionary powers of constraint. ${ }^{14}$

The second prong of Dicey's rule of law means 'equality before the law, or the equal subjection of all classes to the ordinary law of the law administered by the ordinary law courts'. ${ }^{15}$ He explained this as follows:

We mean, in the second place, when we speak of the 'rule of law' as a characteristic of our country, not only that with us no man is above the law, but (what is a different thing) that here every man, whatever be his rank or condition, is subject to the ordinary law of the realm and amenable to the jurisdiction of the ordinary tribunals. ${ }^{16}$

Third, according to Dicey, the rule of law entails that the laws of the constitution ... are not the source but the consequence of the rights of individuals, as defined and enforced by the courts' ${ }^{17}$ This last element is really a 'special attribute of English institutions', that is, of British constitutionalism. He also wrote:

We may say that the constitution is pervaded by the rule of law on the ground that the general principles of the constitution (as for example the right to personal liberty, or the right of public meeting) are with us the result of judicial decisions determining the rights of private persons in particular cases brought before the courts; whereas under many foreign constitutions the security (such as it is) given to the rights of individuals results, or appears to result, from the general principles of the constitution. ${ }^{18}$

A common misreading of the last element in Dicey's theory holds that the rule of law requires the recognition of some minimal substantive rights and freedoms for individuals. As Paul Craig pointed out, however, this

12 AV Dicey, Introduction to the Study of the Law of the Constitution, 10th edn (London: Macmillan, 1961) p 202.

13 Ibid.

14 Ibid, p 188.

15 Ibid, p 202.

16 Ibid, p 193 [footnotes omitted].

17 Ibid, p 203.

18 Ibid, pp 195-6 [footnotes omitted]. 
'is not what Dicey actually said'. ${ }^{19}$ Rather, Dicey simply suggested that, provided a society wishes to give protection to individual rights, that is, if and only if there has been a political will to provide such legal guarantees, then, one way of doing it is better than another way as far as the rule of law is concerned. Namely, the British common law technique ought to be favoured over the Continental written constitutional document technique. This point is important because 'Dicey's third limb of the rule of law is no more substantive than the previous two', as Craig put it: 'It no more demands the existence of certain specific substantive rights than do the earlier limbs of his formulation'.$^{20}$

\section{B. The Critics of the Rule of Law}

To summarise, for Dicey, the constitutional principle of the rule of law involves: (1) being ruled by law and not by discretionary power; (2) equality before the law, for private individuals as well as government officials; and (3) being subject to the general jurisdiction of ordinary courts, which is the best source of legal protection. These core ideas, in one form of another, can be found in the scholarship of most modern authors who have written on the question, whether in the legal studies or the political science literature. ${ }^{21}$

This does not mean, however, that there is any kind of consensus or agreement on the meaning and scope of the rule of law; in fact, the opposite seems to prevail. Some criticisms have been voiced over the years on the vagueness and uncertainty of the concept, with Joseph Raz famously calling the rule of law a mere slogan;22 borrowing from Walter Gallie, ${ }^{23}$ one author suggested it was an 'essentially contested concept. ${ }^{24}$ Witness also the harsh assessment given by Judith Shklar:

It would not be very difficult to show that the phrase 'the Rule of Law' has become meaningless thanks to ideological abuse and general over-use. It may well have become just another one of those self-congratulatory rhetorical devices that grace the public utterances of Anglo-American politicians. No intellectual effort need therefore be wasted on this bit of ruling-class chatter. ${ }^{25}$

19 P Craig, 'Formal and Substantive Conception of the Rule of Law: An Analytical Framework' [1997] Public Law 467 at 473.

20 Ibid, p 474.

${ }^{21}$ See J Stapleton, 'Dicey and his Legacy' (1995) 16 History of Political Thought 234; and J Rose, $\mathrm{n} 5$ above, $\mathrm{p} 458$.

${ }^{22} \mathrm{~J} \mathrm{Raz}$, 'The Rule of Law and its Virtue', in J Raz, The Authority of Law: Essays on Law and Morality (Oxford: Clarendon Press, 1979)) p 210.

${ }^{23}$ WB Gallie, 'Essentially Contested Concepts' (1955-56) 56 Proceedings of the Aristotelian Society 167.

${ }^{24}$ See J Waldron, 'Is the Rule of Law an Essentially Contested Concept (in Florida)?' (2002)

21 Law and Philosophy 137.

${ }^{25}$ Shklar, $\mathrm{n} 4$ above, p 1. 
Similarly, George Fletcher famously referred to the rule of law as the most puzzling 'of all the dreams that drive men and women into the streets'. ${ }^{26}$

\section{Categorising the Rule of Law}

In an attempt to introduce some semblance of order into the discourse on the rule of law, some scholars have put the different versions or formulations of the concept into categories or models. Paul Craig suggested drawing a distinction between the formal conceptions of the rule of law, concerned with how the law is made and its essential attributes (clear, prospective), and the substantive conceptions of the rule of law, concerned not only with the formal precepts but also with some basic content of the law (justice, morality). ${ }^{27}$ Brian Tamanaha picked up this classification and further divided up the formal and substantive models, making the alternative versions go progressively from 'thinner' to 'thicker' accounts, that is, moving from versions with fewer requirements to ones with more requirements, with each subsequent version including the components of the previous ones. Thus, starting with the formal conceptions of the rule of law, the thinnest is (1) the 'rule-by-law' (law as instrument of government), then (2) 'formal legality' (law that is general, prospective, clear, certain), with the thickest of the formal versions adding (3) 'democracy' to legality (consent determines content of law); this is then followed by the substantive conceptions of the rule of law, which all encompass the formal elements but also refer to other legal features such as (4) 'individual rights' (property, contract, privacy, autonomy), as well as a thicker-still version, which includes (5) 'rights of dignity and/or justice' and, finally, the thickest of the models of the substantive rule of law, and indeed of all versions, entailing a dimension of (6) 'social welfare' (substantive equality, welfare, preservation of community). ${ }^{28}$

For the purposes of the present chapter, which concerns the externalisation of the rule of law, the formal understanding of the concept suffices. In fact, to address legality per se at the international level is already a monumental task, not to speak of an inquiry into whether the legal rules in question amount to good law or bad law. Joseph Raz's comments are of relevance here:

If the rule of law is the rule of the good law then to explain its nature is to propound a complete social philosophy. But if so the term lacks any useful function. We have no need to be converted to the rule of law just in order to

${ }^{26}$ GP Fletcher, Basic Concepts of Legal Thought (New York: Oxford University Press, 1996) p 11.

${ }^{27}$ Craig, $n 19$ above.

28 Tamanaha, n 9 above, pp 91ff. 
discover that to believe in it is to believe that good should triumph. The rule of law is a political ideal which a legal system may lack or possess to a greater or lesser degree. That much is common ground. It is also to be insisted that the rule of law is just one of the virtues by which a legal system may be judged and by which it is to be judged. ${ }^{29}$

These remarks apply a fortiori to the present study, which identifies the core features of the rule of law with a view to analysing the situation on the international plane. In this context, Robert Summers is right to note that insofar as formal conceptions of the rule of law are contentindependent, political neutrality makes them preferable to substantive versions, ${ }^{30}$ which, it should be added, is especially the case outside the national realm. But having said that, the formal features of the rule of law must be understood broadly, as the classical notion of 'formalism' allows us to do, namely as including all the attributes of a thing-here, law - that are of such significance as to define it. ${ }^{31}$

\section{Formal Versions of the Rule of Law}

When focusing on the formal conceptions of the rule of law, it is useful to examine the work of Friedrich Hayek, who elaborated on the core ideas expressed by Dicey. Hayek's definition of the rule of law, taken from The Road to Serfdom, has undoubtedly over the years become one of the most influential:

[S]tripped of all technicalities this [the rule of law] means that government in all its actions is bound by rules fixed and announced beforehand-rules which make it possible to foresee with fair certainty how the authority will use its coercive powers in given circumstances, and to plan one's individual affairs on the basis of this knowledge. ${ }^{32}$

As he argued in another book, The Political Idea of the Rule of Law, legal systems adhering to the rule of law have three necessary attributes: 'the laws must be general, equal and certain'. ${ }^{33}$

A number of scholars in legal studies and social and political sciences have followed this modest, largely positivist version of the rule of law, advocating limited models that emphasise the formalistic or processoriented aspects. Lon Fuller, for instance, argues in favour of a system of general rules, which are created and applied consistently with

29 Raz, n 22 above, p 211.

30 See R Summers 'A Formal Theory of the Rule of Law' (1993) 6 Ratio Juris 12.

31 See M Stone, 'Formalism' in J Coleman and S Shapiro (eds), The Oxford Handbook of Jurisprudence (Oxford: Oxford University Press, 2002) p 166.

32 FA Hayek, The Road to Serfdom (London: Routledge, 1944) p 54.

33 FA Hayek, The Political Idea of the Rule of Law (Cairo: National Bank of Egypt, 1955) p 34. 
procedural justice and fairness. ${ }^{34}$ Accordingly, eight conditions must be met: (1) a system of rules; (2) promulgation and publication of the rules; (3) avoidance of retroactive application; (4) clear and intelligible rules; (5) avoidance of contradictory rules; (6) practicable rules; (7) consistency of rules over time and (8) congruence between official actions and declared rules. ${ }^{35}$ To borrow Jeremy Waldron's image, this is 'a sort of laundry list of features that a healthy legal system should have' ${ }^{36}$ A similar enumeration of eight factors essential to the rule of law is given by John Finnis, which all relate to formal aspects of law; that is, to attributes of law that are so significant to law as to define what law is. ${ }^{37}$

Joseph Raz, too, proposes a list of, yet again, eight elements that ought to be found in a rule of law system. However, they are slightly differently formulated than Fuller's and Finnis's, although there is considerable overlap with the latter's list: (1) all law should be prospective, open and clear; (2) law should be relatively stable; (3) the making of particular laws (particular legal orders) should be guided by open, stable, clear and general rules; (4) the independence of the judiciary must be guaranteed; (5) the principles of natural justice must be observed; (6) the courts should have review powers over the implementation of the other principles; (7) the courts should be easily accessible and (8) the discretion of the crime-preventing agencies should not be allowed to pervert the law. ${ }^{38}$ This list, Raz continues, is merely illustrative and is not meant to be exhaustive. In fact, he opines that all of these factors boil down to one proposition: 'in the final analysis the doctrine [of the rule of law] rests on its basic idea that the law should be capable of providing effective guidance' ${ }^{39}$ In his more recent writings on the subject, in Ethics in the Public Domain, Raz spoke of the rule of law quite singularly in terms of the 'principled faithful application of the law'. ${ }^{40}$

At this stage of the discussion, it feels as though we have come full circle, back to Dicey's core idea that the rule of law 'connotes a climate of legality and of legal order' ${ }^{41}$ With a little more meat on the bones, the three limbs remain: (1) the existence of principled normative rules, (2) adequately created and equally applicable to all legal subjects and

\footnotetext{
34 L Fuller, The Morality of Law, 2nd edn (New Haven, CT: Yale University Press, 1969).

35 Ibid, pp 38-9.

36 Waldron, n 24 above, p 154.

37 J Finnis, Natural Law and Natural Rights (Oxford: Clarendon Press, 1980) p 270.

38 Raz, n 22 above, pp 214-18.

39 Ibid, p 218.

$40 \mathrm{~J}$ Raz, Ethics in the Public Domain: Essays on the Morality of Law and Politics (Oxford: Clarendon Press, 1994) p 373.

41 ECS Wade (ed), in his introduction to the 10th edition of Dicey's Introduction to the Study of the Law of the Constitution, $\mathrm{n} 12$ above, $\mathrm{p} \mathrm{cx}$.
} 
(3) enforced by accessible courts of general jurisdiction. These characteristics shall now be externalised, as the discussion moves to whether or not they are reflected onto the international plane.

\section{THE RULE OF LAW EXTERNALISED}

It is first important to clarify what is meant by externalisation. It is the process by which a feature or characteristic that exists within the inside set is projected or attributed to circumstances or causes that are present in the outside space according to an internal-external dichotomous structure. To give an example, let us take the terminology of 'sovereignty', a concept that was articulated in modern terms during the sixteenth century by Frenchman Jean Bodin. ${ }^{42}$ The history of the word 'sovereignty' shows that, in the eighteenth century, the Swiss author Emer de Vattel externalised the main ideas associated with this internal (domestic) notion and made sovereignty relevant for the discourse of international law; in fact, it became one of its core foundational principles. ${ }^{43}$ My goal with the rule of law is more modest, of course, but the task at hand is to pick up the essential elements of the concept, understood in its formal versions, and examine in what ways they may be found in international law. Accordingly, this section will assess: (1) the existence of principled legal normativity on the international plane; (2) how these norms are made and are applicable equally to all legal subjects and (3) the way in which normativity is enforced through adjudication.

A word of caution is in order at this point. Just as sovereignty could only be externalised mutatis mutandis ${ }^{44}$ by Vattel, the present project requires some material adjustments to the features of the rule of law in order to take into account the different nature of the international legal order. What are these distinctions between domestic legal systems and the international legal system? Drawing an exhaustive list is both extremely difficult and somewhat futile, but the following categories of distinctions may be offered and should be borne in mind during the process of externalising the rule of law. They relate to the sources of law, to legal subjects and to compliance. In summary, there is no one formal norm-creating authority on the international level; states (not individuals) remain the principal legal actors and there is no enforcement mechanism (such as a police force).

42 See S Beaulac, 'The Social Power of Bodin's "Sovereignty" and International Law' (2003) 4 Melbourne Journal of International Law 1.

${ }^{43}$ See S Beaulac, 'Emer de Vattel and the Externalization of Sovereignty' (2003) 5 Journal of the History of International Law 237.

${ }^{44}$ That is, with respective differences taken into consideration. 


\section{A. Principled Legal Normativity}

In a recent article on the relationship between international law and domestic law, Mattias Kumm uses a form of externalised rule of law. ${ }^{45}$ He too discards the substantive versions of the concept and concentrates on the narrower understanding, that is, what he suggests is the literal meaning of the expression, namely to rule 'by law' $^{\prime} .^{46}$ It has already been explained above why, like Kumm, I believe that it is the formal rule of law that ought to be externalised on the international plane, bearing in mind that 'formalism' refers to the attributes of law that are so significant to it as to define what law is. ${ }^{47}$ To be ruled by law (that is, government by law, not by men) at the international level means, according to Kumm, the following: "The addressees of international law, states in particular, should obey the law. They should treat it as authoritative and let it guide and constrain their actions. ${ }^{48}$ The international rule of law requires at the very least some basic legal ordering of affairs within a society, which international society no doubt enjoys.

Today, indeed few people would seriously doubt that there is a body of norms that enjoy the characteristics and pedigree of law on the international plane ${ }^{49}$ International law is regarded as true positive law, which forms part of a real legal system, in which 'every international situation is capable of being determined as a matter of law', ${ }^{50}$ as Robert Jennings and Arthur Watts have put it. These two British authors also argue that the legal determination of such issues occurs 'either by the application of specific legal rules where they already exist, or by the application of legal rules derived, by the use of known legal techniques, from other legal rules or principles'. ${ }^{51}$ Whilst framed in positivist legal terms, and thus open to possible strong objections, ${ }^{52}$ the following discussion favours a concept of law that is broad enough to include international law.

\section{i. Certainty, Predictability and Stability}

Borrowing from Dicey, but also from Hayek and Raz, the rule of law requires that normativity reach a degree of development sufficient to

\footnotetext{
45 M Kumm, 'International Law in National Courts: The International Rule of Law and the Limits of the Internationalist Model' (2003-04) 44 Virginia Journal of International Law 19.

46 Ibid, p 22.

47 See nn 30-31 above and accompanying text.

48 Kumm, n 45 above, p 22.

49 See TM Franck, Fairness in International Law and Institutions (New York: Oxford University Press, 1995), who speaks of the post-ontological era of international law.

50 R Jennings and A Watts, Oppenheim's International Law, Vol 1, 9th edn (London: Longman, 1992) pp 12-13.

51 Ibid.

52 See the classic piece by GL Williams, 'International Law and the Controversy Concerning the Word "Law"' (1945) 22 British Yearbook of International Law 146.
} 
provide for certainty, predictability and stability. These values are not absolute, however, and some degree of vagueness and uncertainty in law is inevitable in any legal system, be it national or international. At the national level, both the US and Canada, for instance, have developed socalled 'void for vagueness' doctrines that address the need for certainty and predictability in domestic statutes, with intelligibility standards that allow for a good dose of 'open texture' in legislative language, to quote from Hart. ${ }^{53}$

At the international level, the sources of international law are set out in the Statute of the International Court of Justice (ICJ Statute) ${ }^{54}$ at Article $38(1)$, the principal ones being treaties, customs and general principles of law. Here, a fundamental difference between international and domestic legal systems ought to be mentioned at the outset, thus justifying a slight adjustment in the required level of certainty in the law. Arthur Watts explained it thus:

[I]nternational law has no central legislator, nor any legislative process in the normal (municipal) sense of the term; its norm-creating process is essentially decentralised, and so far as international conferences or meetings within international organisations may produce quasi-legislative texts the outcome represents 'legislation' by negotiation and compromise, which is not a process calculated to produce precision and clarity. ${ }^{55}$

This being so, the level of certainty, predictability and stability shown by international legal norms, assessed according to a somewhat reduced standard justified under the international rule of law, are no doubt adequate in a number of different substantive areas. They include international human rights law, international economic law, international labour law, international humanitarian law, the international law of the sea, the international law of state responsibility and international criminal law.

\section{ii. Limiting Discretionary (Arbitrary) Power}

The argument for a minimal rule of law at the international level finds further support when one recalls that the ideal of the rule of law with regard to the existence of principled legal normativity relates to the need to circumscribe sovereignty which, in its absolute form, may lead to arbitrary power. The issue boils down to how a system can limit or curtail the discretionary power of those who hold authority in a given society. When transposed onto the international plane, it is sovereignty understood

${ }^{53}$ HLA Hart, 'Positivism and the Separation of Law and Morals' (1957-58) 71 Harvard Law Review 593.

541 UNTS xvi.

55 A Watts, 'The International Rule of Law' (1993) 36 German Yearbook of International Law 15 at 28. 
externally that must be addressed through the international rule of law. The definition of external sovereignty given by Arbitrator Huber in the Island of Palmas case thus remains very relevant indeed for the present discussion: 'Sovereignty in the relations between states signifies independence. Independence in regard to a portion of the globe is the right to exercise therein, to the exclusion of any other State, the functions of a State. ${ }^{\prime 56}$

However, external sovereignty also means that, vis-à-vis the outside world, states have absolute power that is unrestricted but for the first ideal of the (international) rule of law, namely the existence of a system of positive law. Judge Anzilotti, writing a separate opinion in the AustroGerman Customs Union case, encapsulated this feature well when he spoke of 'sovereignty (suprema potestas), or external sovereignty, by which is meant that the State has over it no other authority than that of international law' ${ }^{57}$ The sovereign independence of states, allowing for unrestricted assertions of power, must be balanced-and indeed is balanced-by the ideal of the international rule of law relating to principled legal normativity. Arthur Watts put it as follows:

It is, of course, the case that States on occasion act in breach of the law, and perhaps even sometimes in complete and wilful disregard of the law ... What the rule of law requires is that in their international relations States conduct themselves within an essentially legal framework; it is action which is despotic, capricious, or otherwise unresponsive to legal regulation which is incompatible with the international rule of law. ${ }^{58}$

Although a detailed empirical demonstration of the argument will have to wait for another day, it may nevertheless be suggested with confidence that the extensive body of international legal rules in many substantive areas, referred to above, does limit and curtail the exercise of discretionary power, as well as arbitrary power, by states in their relations with others. ${ }^{59}$

\section{B. Adequate Creation and Equal Application of Legal Norms}

Many international legal scholars, including perhaps Mattias Kumm, ${ }^{60}$ would stop here and acknowledge the 'international rule of law' because its one principal ingredient has been found. At the normative level, the conduct of states in their relations is 'ruled by law', that is, by international

56 Island of Palmas case (1928) 2 RIAA 829, at 838.

57 Austro-German Customs Union case (1931), PCIJ Series A/B, no 41, p 57.

58 Watts, n 55 above, p 33.

59 Ibid, p 23.

60 Note 45 above. 
normativity that is sufficiently certain, predictable and stable. The minimum exists on the international plane; the first leg of Dicey's rule of law theory. But what about the international rule of law in its functional dimensions? More specifically, how are norms created in the international realm and do they apply equally to all legal subjects?

\section{i. Promulgation and Publication}

The first part of the inquiry essentially pertains to the promulgation and publication of written legal norms. To borrow from Raz, this rule of law value concerns the making of laws, which should be guided by open, stable, clear and general principles. ${ }^{61}$ In the context of domestic law, the activity studied under this heading is legislation, the main source of written legal norms, with the analysis scrutinising the parliamentary process of legislative enactment. In the context of international law, the (imperfect) parallel is with treaties, one of the three formal sources of law under Article 38(1) of the Statute of the International Court of Justice and the source of written legal norms on the international plane, as opposed to customs that constitute the source of international nonwritten rules. ${ }^{62}$ The general principles of law are also of less interest because, by definition, they are extracted from domestic legal systems (in foro domestico) and, accordingly, should be deemed to pursue rule of law values.

When focusing on the process by which written normativity is promulgated by means of treaties on the international plane, one is struck by the level of sophistication in the relevant rules found in the 1969 Vienna Convention on the Law of Treaties. ${ }^{63}$ Some 108 states have ratified the Vienna Convention, ${ }^{64}$ which has been in force since January 1980; even those states that are not conventionally bound by it recognise that, for the most part, the rules contained in it do nevertheless apply to them because they also reflect customary international law. ${ }^{65}$ In short, it is one of the most universal international instruments, second perhaps only to the Charter of the United Nations. ${ }^{66}$ In any event, for our purposes, it is sufficient to say that the Vienna Convention provides for all essential aspects

$61 \mathrm{~J}$ Raz, n 22 above, p 215.

62 On the judge-made-law/customary international law parallel, see S Beaulac, 'Customary International Law in Domestic Courts: Imbroglio, Lord Denning, Stare Decisis' in CPM Waters (ed), British and Canadian Perspectives on International Law (Leiden: Martinus Nijhoff, 2006) p 379 at p 392.

631155 UNTS 331 (1969).

64 As of 1 January 2007.

65 See MN Shaw, International Law, 5th edn (Cambridge, Cambridge University Press, 2003) p 633.

66 Charter of the United Nations (not published in the UNTS), Can TS 1945 No 7 (1945). 
of international treaties: conclusion, ratification, reservations application, interpretation, validity, termination, and so on.

With respect to the publication of conventional international law, it should be pointed out that transparency has been formally laid down as a guiding principle since 1945 with the signing of the Charter of the United Nations, Article 102 of which provides that only treaties registered with the Secretariat can be invoked within the UN system. This essential requirement is also found in Article 80(1) of the Vienna Convention on the Law of Treaties. They are all published, updated and, nowadays, readily available in electronic form; ${ }^{67}$ in fact, not only the UN but also domestic legal agencies in many states make treaties easily accessible to the public. ${ }^{68}$ Accessibility has become markedly less problematic following the advent of the internet.

\section{ii. Universality and Sovereign Equality}

Does the existing system of legal norms based on treaties, as well as on other sources of law such as custom and general principles of law, apply equally to all legal subjects? Equality is indeed the other functional dimension of the rule of law that must be examined. It is important to recall one of the distinctive features of the international legal order, namely that states continue to be the principal actors on the international plane by virtue of the fact that they have inherent and unrestricted legal personalities (something, of course, that international organisations, corporations and individuals do not have). At risk of being branded overly traditionalist, I shall limit the discussion to the situation of states and how international law treats them; equality as it relates to non-state actors (although, intuitively, leading to similar conclusions) is a question for another occasion.

One angle to the issue of equality concerns universality; that is, whether or not international law applies to all the states in the world. Not too long ago, international law was, to a very large extent, the public law of Europe, relevant to the states of that continent; ${ }^{69}$ everywhere else was basically terra nullius, available for colonisation or other forms of territorial exploitation. ${ }^{70}$ This situation has, of course, drastically changed, with the different phases of decolonisation in Latin America and in Africa up until the early 1970s, and the latest episodes of liberation from Soviet

67 See the following website: http://untreaty.un.org/.

68 See, for example, in Canada, the following website: http://www.treaty-accord.gc.ca/.

69 See A Orakhelashvili, 'The Idea of European International Law' (2006) 17 European Journal of International Law 315 at 336-8.

70 See AP Rubin, 'International Law in the Age of Columbus' (1992) 29 Netherlands International Law Review 5; and MF Lindley, The Acquisition and Government of Backward Territories in International Law (London: Longmans, Green, 1926). 
imperialism in Eastern Europe and in many parts of Asia during the 1990s. ${ }^{71}$ Membership of the international community is now truly global, therefore making international law fully universal both in scope and in reach. There are, of course, some international legal scholars who love to remind us that international law was born in Europe and that there are, no doubt, continuing biases in favour of Western interests and ideologies. ${ }^{72}$ But none of these authors would dare question the universality of international law, or dispute that its normativity is applicable to all members of the international community.

One primordial value of the rule of law-found in Dicey, Hayek and Raz, as well as others-relates to the need for all legal subjects to enjoy equality before the law. In international law, there is a long-standing principle, dating back to the classical legal scholarship on the subject, that all states of the international community, although (like human beings) not at all equal in absolute terms, ${ }^{73}$ stand equally within the normative system. ${ }^{74}$ Already in the eighteenth century, Emer de Vattel wrote the following on the legal equality of states:

Since men are naturally equal, and a perfect equality prevails in their rights and obligations, as equally proceeding from nature-Nations composed of men, and considered as so many free persons living together in a state of nature, are naturally equal, and inherit from nature the same obligations and rights. Power or weakness does not in this respect produce any difference. A dwarf is as much a man as a giant; a small republic is no less a sovereign state than the most powerful kingdom. ${ }^{75}$

Accordingly, equality of states in international law means that 'whatever is lawful for one nation is equally lawful for any other; and whatever is unjustifiable in the one is equally so in the other ${ }^{\prime}{ }^{76}$

Since the signing of the Charter of the United Nations, we speak of the sovereign equality of states, ${ }^{77}$ which constitutes one of the seven principles of the organisation as set out in Article 2. With the Declaration on Principles of International Law Concerning Friendly Relations and

71 See, generally, M Koskenniemi, The Gentle Civilizer of Nations (Cambridge: Cambridge University Press, 2002).

72 See M Koskenniemi, 'International Law in Europe: Between Tradition and Renewal' (2005) 16 European Journal of International Law 113.

73 See RW Tucker, The Inequality of Nations (New York: Basic Books, 1977).

74 See B Kingsbury, 'Sovereignty and Inequality' (1998) 9 European Journal of International Law 599 at 599.

75 E de Vattel, The Law of Nations; or, Principles of the Law of Nature, applied to the Conduct and Affairs of Nations and Sovereigns, trs J Chitty (Philadelphia, PA: Johnson Law Booksellers, 1863) p lxii.

76 Ibid.

77 On the origin and the development of the expression 'sovereign equality' in international law, see RA Klein, Sovereign Equality Among States: The History of an Idea (Toronto: Toronto University Press, 1974). 
Co-operation Among States in Accordance with the Charter of the United Nations, ${ }^{78}$ a General Assembly resolution adopted by the United Nations in 1970, sovereign equality became one of the basic principles of international law. 'All States enjoy sovereign equality,' it reads. 'They have equal rights and duties and are equal members of the international community, notwithstanding differences of an economic, social, political or other nature.' In particular, it provides that sovereign equality entails that states are 'juridically equal', that is to say, all members of the international community are equal in the eyes of the law.

The meaning of sovereign equality in international law for the purpose of the international rule of law must be explained further. Of course, it cannot mean that all legal norms apply to every state in the same way; some of them may only apply to certain states because of their situations. ${ }^{79}$ For instance, landlocked states are not submitted to most of the regime of the 1982 United Nations Convention of the Law of the Sea, ${ }^{80}$ without thereby prejudicing whatsoever any equality value. What matters, really, is that no discrimination occurs in the way in which international normativity applies to states. If you are a coastal state, the legal regime will apply to you just as it applies to all the other coastal states around the world, whether large or small, whether powerful or weak, whether militarily expansionist or pacifist. Arthur Watts explicated thus:

[A]ll States which come within the scope of a rule of law [i.e. international legal norm] must be treated equally in the application of that rule to them. There must, in other words, be uniformity of application of international law and no discrimination between States in their subjection to rules of law [i.e. international legal norms] which in principle apply to them. ${ }^{81}$

Put in those terms, there is little doubt that the normativity on the international plane applies equally to all states, which are the main legal subjects. In practice, there may be cases where one might wonder whether, for instance, the prohibition on the use of force applies in the same way to a superpower like the US, an obvious question in relation to the illegal invasion and occupation of Iraq. The theory remains clear, however, in that sovereign equality entails similarly situated states being treated in the same way by international law, with no discriminatory treatment tolerated by the system.

There is another aspect of the sovereign equality of states that should be noted for the present purposes, namely that states are not only equal in how legal norms apply to them, but are also equal in how they

78 GA Res 2625 (XXV), UN Doc A/8028 (1970).

${ }^{79}$ Watts, $\mathrm{n} 55$ above, p 31.

801833 UNTS 396 (1982).

81 Watts, n 55 above, p 31. 
participate in the creation of international normativity. ${ }^{82}$ In relation to treaties, Article 6 of the Vienna Convention on the Law of Treaties provides: 'Every State possesses the capacity to conclude treaties.' It is also significant that treaty-making conferences generally favour an egalitarian procedure of one state, one vote for the negotiation and adoption of treaty texts. Moreover, the systems of reservations, entry into force, modification and termination of treaties, found in the Vienna Convention, assume that states participate equally in conventional regimes. As regards customary international law, a similar reasoning based on the ideal of sovereign equality is adopted. ${ }^{83}$ Indeed, the practice of every state with an interest in the legal issue (see the example of the law of the sea, above) as well as their opinion juris are both significant in the process of determining whether a custom has formed. ${ }^{84}$ This equal role in the formulation of international normativity provides further strength to the claim that the value of the rule of law relating to equality is projected onto the international plane.

\section{Adjudicative Enforcement of Normativity}

We now turn to what is without doubt the most difficult set of formal values associated with the rule of law in terms of externalisation onto the international plane, namely the presence of courts of general jurisdiction which are easily accessible to legal subjects for the adjudication of disputes ruled by international normativity. A few distinguishing aspects of the international legal system must be taken into account, with a view to adjusting the terms of inquiry into how these elements are reflected internationally. Here, too, the fact that states are the main (though no longer exclusive) subjects of international law is again relevant, which explains why the following discussion considers international judicial enforcement in the traditional sense, that is to say in cases involving disputes between states. In fact, the focus is on the International Court of Justice, 'the principal judicial organ of the United Nations', according to Article 92 of the Charter of the United Nations, and by far the most important in the international legal system. It is also useful to recall yet another distinctive feature of the international

82 See N Krisch, 'More Equal than the Rest? Hierarchy, Equality and US Predominance in International Law' in M Byers and G Nolte (eds), United States Hegemony and the Foundations of International Law (Cambridge: Cambridge University Press, 2003) p 135.

${ }^{83}$ See SJ Toope, 'Powerful but Unpersuasive? The Role of the USA in the Evolution of Customary International Law' in M Byers and G Nolte (eds), United States Hegemony and the Foundations of International Law (Cambridge: Cambridge University Press, 2003) p 135.

${ }^{84}$ See, generally, MH Mendelson, 'The Formation of Customary International Law' (1998) 272 Recueil des Cours 155. 
legal system, namely that there is no system for guaranteeing ultimate compliance if states refuse to follow judicial decisions. ${ }^{85}$ This characteristic, however, must not be overstated with the suggestion that judgments in international law are not binding. On the contrary, they are indeed binding on the parties to the case pursuant to Article 94 of the Charter of the United Nations, an aspect that will be explored in greater detail below. ${ }^{86}$

\section{i. Court of General Jurisdiction}

Having now made these preliminary points, the analysis will proceed first with the issue of whether international normative adjudication falls within a general jurisdiction. There is no doubt that there is a judicial structure on the international plane, at the centre (though not the apex) of which is the International Court of Justice, which can deal with all legal disputes between states. The so-called 'fragmentation' of international law due to the multiplicity of international adjudicative bodies has recently caused much ink to flow in international legal circles, the report by the International Law Commission (led by Martti Koskenniemi) being the latest manifestation. ${ }^{87}$ For present purposes, the risk that the many adjudicative bodies might apply international law differently, and so create 'boxes's8 of normativity and 'self-contained regimes', 89 can be dismissed. The intuition is that, under the leadership of the International Court of Justice, the dangers of fragmentation are manageable.

In theory, the jurisdiction of the International Court of Justice over contentious matters is plenary, as far as states are concerned..$^{90}$ With respect to ratione personae jurisdiction, Article 34(1) of the ICJ Statute is clear: 'Only states may be parties in cases before the Court.' In regard to ratione materiae jurisdiction, Article 36(1) provides: 'The jurisdiction of the Court comprises all cases which the parties refer to it and all matters specially provided for in the Charter of the United Nations or in treaties and

\footnotetext{
85 See, generally, B Kingsbury, 'The Concept of Compliance as a Function of Competing Conceptions of International Law' (1998) 19 Michigan Journal of International Law 345.

86 See nn 116-20 below and accompanying text.

87 International Law Commission, 'Fragmentation of International Law: Difficulties Arising from the Diversification and Expansion of International Law', Report of the Study Group, 58th Session (2006), Doc A/CN/.4/L.682.

88 On the theory of 'boxes', see M Koskenniemi, 'International Law: Constitutionalism, Managerialism and the Ethos of Legal Education' (2007) 1 European Journal of Legal Studies, availanle at www.ejls.eu/.

${ }^{89}$ See B Simma and D Pulkowski, 'Of Planets and the Universe: Self-contained Regimes in International Law' (2006) 17 European Journal of International Law 483.

90 See RY Jennings, 'The Role of the International Court of Justice' (1997) 68 British Yearbook of International Law 1.
} 
conventions in force.' Under Article 65(1) of the ICJ Statute, the Court also has jurisdiction to give advisory opinions in non-contentious matters, ${ }^{91} \mathrm{a}$ procedure that can be initiated not only by states, but also by 'whatever body [that] may be authorized by or in accordance with the Charter of the United Nations to make such a request'. At first glance, therefore, the jurisdiction of the International Court of Justice seems to be comprehensive; one may even be tempted to draw an analogy with the inherent jurisdiction of domestic courts.

Of course, this picture is a mere illusion, as the jurisdiction of the International Court of Justice is anything but comprehensive, let alone inherent. Indeed, it is well known that the contentious jurisdiction of the Court depends in all cases on whether or not the states involved have consented to the judicial proceedings. ${ }^{92}$ This feature is usually referred to as the lack of compulsory jurisdiction of the International Court of Justice- or any international adjudicative body for that matter ${ }^{93}$-over contentious matters. To put it another way, states cannot be forced to appear before a court or tribunal in order to settle a legal dispute by means of adjudication. This position is explained by the traditional notion of state sovereignty and by the voluntary (that is, consensual) normative theory of international law. ${ }^{94}$ At this point of the inquiry, I would agree with Arthur Watts that: 'Such a purely consensual basis for the judicial settlement of legal disputes cannot be satisfactory in terms of the rule of law. ${ }^{95}$

However, the situation proves to be not so bad given that, in reality, states do not have to consent on a case-by-case basis each time they are involved in a legal dispute. States can give their consent in advance to the jurisdiction of an adjudicative body in regard to future disputes; with respect to the ICJ, as Article 36(2) of the ICJ Statute provides that states

may at any time declare that they recognize as compulsory ipso facto and without special agreement, in relation to any other state accepting the same obligation, the jurisdiction of the Court in all legal disputes concerning:(a) the interpretation of a treaty; (b) any question of international law; (c) the existence of any fact which, if established, would constitute a breach of an international obligation; (d) the nature of extent of the reparation to be made for the breach of an international obligation.

91 See P-O Savoie, 'La CIJ, l'avis consultative et la fonction judiciaire: entre décision et consultation' (2005) 42 Canadian Yearbook of International Law 35.

92 See S Rosenne, The Law and Practice of the International Court, 1920-2005, Vol II, Jurisdiction (Leiden: Martinus Nijhoff, 2006) p 549.

93 See, generally, J Allain, A Century of International Adjudication-The Rule of Law and its Limits (The Hague: TMC Asser Press, 2000).

${ }^{94}$ See Rosenne, n 92 above, pp 549-50.

95 Watts, n 55 above, p 37. 
This is known as the 'optional clause' to the contentious jurisdiction of the International Court of Justice. ${ }^{96}$

There are commitments to the same effect found in a number of other treaties, by which states consent in advance to the jurisdiction of an international court to settle legal disputes covered by the conventional regime. These dispute settlement provisions may be optional, leaving states the option to accept the jurisdiction as cases arise, or they may be mandatory for parties to the treaty, thus leaving no choice as to whether to submit to the adjudicative body in a particular dispute. This latter situation, as well as those involving the ICJ 'optional clause', is the closest one gets to a general jurisdiction on the international plane. Although not a perfect scenario, it goes in the right direction in pursuing the value of the rule of law pertaining to the enforcement of normativity, especially given the reality of state sovereignty in the international realm. ${ }^{97}$

\section{ii. Judicial Review}

An issue related to that of general jurisdiction is whether or not the International Court of Justice has competence to exercise judicial review of the decisions and actions of the other organs of the United Nations system, ${ }^{98}$ including the Security Council. The power to review the acts of the latter is the most difficult-and controversial-question; in a sense, however, an affirmative answer would lay the ground for recognising a general competence of international judicial review for the ICJ. This would be a clear gain for the rule of law concerning the legality of decisions on the international plane, in particular with respect to the matters falling within the competence of what is considered the 'executive' of the United Nations, the Security Council.

It is instructive to go back to 1945, at the time of the adoption of the Charter of the United Nations in San Francisco, ${ }^{99}$ where Belgium suggested establishing a procedure by which disputes between UN organs over the interpretation of the UN Charter would be referred to the International Court of Justice, thus giving it a sort of supervisory judicial

\footnotetext{
96 See F Orrego Vicuna, 'The Legal Nature of the Optional Clause and the Right of a State to Withdraw a Declaration Accepting the Compulsory Jurisdiction of the International Court of Justice' in N Ando, E McWhinney and R Wolfrum (eds), Liber amicorum Judge Shigeru Oda (The Hague: Kluwer Law International, 2002) p 463.

97 See S Oda, 'The Compulsory Jurisdiction of the ICJ: A Myth? A Statistical Analysis of Contentious Cases' (2000) 49 International and Comparative Law Quarterly 251.

98 See HK Hubbard, 'Separation of Powers within the United Nations: A Revised Role for the International Court of Justice' (1985) 38 Stanford Law Review 165.

99 See, generally, S Rosenne, The Law and Practice of the International Court, 1920-2005, Vol I, The Court and the United Nations (Leiden: Martinus Nijhoff, 2006) pp 57-60.
} 
role. ${ }^{100}$ The proposal was, however, rejected. In the Certain Expenses case, the ICJ gave effect to the intention of the constituting authority not to empower it with a judicial review function:

In the legal systems of States, there is often some procedure for determining the validity of even a legislative or governmental act, but no analogous procedure is to be found in the structure of the United Nations. Proposals made during the drafting of the Charter to place the ultimate authority to interpret the Charter in the International Court of Justice were not accepted. ${ }^{101}$

In the Namibia case in 1971, the Court once again held that it 'does not possess powers of judicial review or appeal in respect of the decisions taken by the United Nations organs concerned'. ${ }^{102}$ In fact, the ICJ has always adopted a sort of presumption of legality in favour of UN organs, which translates into a high degree of judicial deference shown for their decisions. Therefore, save the most fundamental irregularities, there is little (in fact, no) chance of the Court exercising a power of judicial review, especially with respect to the Security Council.

This position represents the traditional thinking on the issue which, however, seems to be in the process of reconsideration. In a recent speech given at the London School of Economics and Political Science, for instance, Judge Rosalyn Higgins, President of the International Court of Justice, asked:

Are these [Security Council's] decisions judicially reviewable for nonarbitrariness and for constitutionality? This is one of the great unanswered questions: The International Court of Justice is a main organ of the UN and its principal judicial organ. Whether it may judicially review the decisions of other organs, taken within the field of their allocated competence, is not yet fully determined. ${ }^{103}$

The Lockerbie case ${ }^{104}$ would have provided the opportunity for the Court to address questions of judicial review insofar as Libya challenged decisions by the Security Council on sanctions in relation to the Pan Am Flight 103 affair. However, the case was withdrawn, leaving these issues to be

100 United Nations, Documents of the United Nations Conference on International Organization (San Francisco Conference, 1945), Vol 13 (New York, United Nations Information Organizations, 1946) pp 645 and 668.

101 Certain Expenses of the United Nations (Art 17, paragraph 2, of the Charter) (1962) ICJ Reports 151 at 168 .

102 Legal Consequences for States of the Continued Presence of South Africa in Namibia (South West Africa) notwithstanding Security Council Resolution 276 (1970) (1971) ICJ Reports 16 at 45.

103 R Higgins, 'The ICJ, the United Nations System, and the Rule of Law', London School of Economics and Political Science, 13 November 2006, p 2, available at www.lse.ac.uk/ collections/LSEPublicLecturesAndEvents/pdf/20061113_Higgins.pdf.

104 Questions of Interpretation and Application of the 1971 Montreal Convention Arising from the Aerial Incident at Lockerbie, Provisional Measures, (1992) ICJ Reports 1. The Lockerbie case was discontinued on 10 September 2003 by Order of the Court, (2003) ICJ Reports 325. 
reconsidered at a later date. There are more signs now, however, that the International Court of Justice is getting ready to embrace a judicial review function, with some even suggesting that it is an emerging general principle of law, ${ }^{105}$ which would be excellent news for the international rule of law.

\section{iii. Independence and Impartiality}

This part of the inquiry, on judicial independence and impartiality, is straightforward because virtually nobody questions these attributes with regard to the International Court of Justice. ${ }^{106}$ In Article 2 of the ICJ Statute the first provision under the heading 'Organization of the Court', provides as follows:

The Court shall be composed of a body of independent judges, elected regardless of their nationality from among persons of high moral character, who possess the qualifications required in their respective countries for appointment to the highest judicial offices, or are jurisconsults of recognized competence in international law.

Judges are elected jointly by the General Assembly and the Security Council of the United Nations, from a list provided by national authorities. Pursuant to Article 33 of the ICJ Statute, the budget of the Court is voted by the General Assembly, although there is obviously no financial accountability between the two.

Impartiality, for its part, is addressed in Article 20 of the ICJ Statute, which provides that: 'Every member of the Court shall, before taking up his duties, make a solemn declaration in open court that he will exercise his powers impartially and conscientiously'. The issues of incompatibility with outside activities and of previous involvement in other cases are regulated in Articles 16 and 17, respectively. With regard to the situation of ad hoc judges and their previous or subsequent work as legal agents, the Court has adopted practice statements. One feature of independence and impartiality is the judge's freedom from dismissal, putting barriers in the way of the removal of judges from office; Article 18(1) of the ICJ Statute provides for the rule: 'No member of the Court can be dismissed unless, in the unanimous opinion of the other members, he has ceased to fulfil the required conditions.'

Beyond these formal elements found in its constituting documents, the Court and its judges do enjoy a high degree of independence

105 See E de Wet, 'Judicial Review as an Emerging General Principle of Law and its Implications for the ICJ' (2000) 47 Netherlands International Law Review 181.

106 See G Guillaume, La Cour internationale de Justice à l'aube du XXIème siècle: Le regard d'un juge (Paris: Pedone, 2003) p 120. 
and have demonstrated great impartiality in practice. As the current President of the International Court of Justice, Judge Rosalyn Higgins, recently said:

Judges [are] nominated nationally but elected by the General Assembly and the Security Council, under terms whereby their conditions of service may not be altered during their tenure. Although the Court reports annually to the General Assembly on its year's work, the judicial decisions are subject to no comment (still less rebuke) by the Assembly or its Members. There is a proper separation of powers, and the Judges of the ICJ are mercifully free of any pressures from their national governments. That the Court applies the law consistently and impartially is doubted nowhere. ${ }^{107}$

Though obviously not a disinterested opinion, it certainly represents the view of the very large majority of states involved in, and of people associated with, the international justice system.

\section{iv. Accessibility}

The courts and tribunals in a legal system must be easily accessible to all its legal subjects, something that is now examined with respect to the International Court of Justice. We saw earlier that, with the exception of the possibility of lodging a request for an advisory opinion, ${ }^{108}$ there is no role for legal actors other than states in ICJ procedures; its contentious jurisdiction is indeed strictly limited to inter-state disputes. ${ }^{109}$ According to Article 35(1) of the ICJ Statute, the Court is open to the states that are parties to this instrument which, in fact, include all the states that are members of the United Nations, ${ }^{110}$ as well as non-member states 'on conditions to be determined in each case by the General Assembly upon the recommendation of the Security Council'. ${ }^{111}$ Pursuant to Article 35(2) of the ICJ Statute, the Court is even open to states that are not parties to this instrument, on conditions laid down again by the Security Council, although 'in no case shall such conditions place the parties in a position of inequality before the Court'. There is an obvious effort to assure equal access and equal status to all states that may appear before of the International Court of Justice, which is indeed in agreement with the spirit of the rule of law as reflected onto the international plane.

107 Higgins, n 103 above, at 3.

108 Note 91 above and accompanying text.

109 Note 90 above and accompanying text.

110 See Art 93(1) of the Charter of the United Nations, which reads: 'All Members of the United Nations are ipso facto parties to the Statute of the International Court of Justice.'

111 Ibid, Art 93(2). 


\section{v. Effectiveness}

Do states follow international law and, in particular, do they submit to the decisions of international adjudicators? In other words, is the international normativity as applied by the international judiciary effective? One recalls what Louis Henkin famously wrote about general compliance with international law: 'It is probably the case that almost all nations observe almost all principles of international law and almost all of their obligations almost all of the time. ${ }^{\prime 12}$ Although less catchy, Arthur Watts' view is to the same effect: 'In practice, the overwhelming tendency of States in their day-today dealings with other States is to apply and abide by international law as a normal part of the regular pattern of international affairs. ${ }^{.13}$

The more important question, insofar as the rule of law value concerning the enforcement of legal norms, is whether or not the decisions by the ICJ, after the full involvement of the international justice system in contentious cases, are followed through by the (losing) states. Put differently, when push comes to shove, and a state must really choose between ultimate compliance with international normativity as decided through adjudication, does it honour the international rule of law? On this issue, remarks made by Judge Rosalyn Higgins, President of the ICJ, are again apposite:

Contrary to a widespread misconception, the Court's Judgments are both binding and almost invariably complied with. Out of the 91 contentious cases that the Court has dealt with since 1946, only 4 have in fact presented problems of compliance and, of these, most problems have turned out to be temporary. ${ }^{114}$

Indeed, there is a perturbing myth among people interested in the international justice system to the effect that states not only retain a discretionary power to comply with international judicial decisions, but actually use it to reject them. Empirically, this is simply not true. ${ }^{115}$

Article 94(1) of the Charter of the United Nations sets out in clear terms the legal obligation to comply with ICJ judgments: 'Each Member of the United Nations undertakes to comply with the decision of the International Court of Justice in any case to which it is a party.' As Shabtai Rosenne noted, however, the broad language is deceptive in its simplicity: 'The undertaking to comply with the decisions of the Court does not indicate in whose favour the undertaking is given', ${ }^{\prime 16}$ for instance.

112 L Henkin, How Nations Behave, 2nd edn (New York: Columbia University Press, 1979) p 47.

113 Watts, n 55 above, p 41.

114 Higgins, n 103 above, p 3.

115 See C Paulson, 'Compliance with Final Judgments of the International Court of Justice since 1987' (2004) 98 American Journal of International Law 434.

116 Rosenne, n 99 above, p 205. 
The vagueness of the relevant terms might explain the suggestion that the International Court of Justice is 'a toothless bulldog'. ${ }^{117}$ But this underestimates the complex dynamics between the different organs of the United Nations when it comes to the enforcement of judicial decisions. ${ }^{118}$ Most importantly, Article 94(2) of the Charter of the United Nations provides that:

If any party to a case fails to perform the obligations incumbent upon it under a judgment rendered by the Court, the other party may have recourse to the Security Council, which may, if it deems necessary, make recommendations or decide upon measures to be taken to give effect to the judgment.

Of course, it must be acknowledged that the Security Council has discretion in this process of enforcement, which makes some say that Article 94(2) 'should not be overestimated as a means for executing judgments of the ICJ, in particular if "veto-powers" [that is, of the five permanent members of the Security Council] are concerned'. ${ }^{119}$ It is also true, however, that the full potential of the judicial enforcement provision of the UN Charter has not been really tested just because, on the ground, judgments of the International Court of Justice are complied with unreservedly in almost all instances. ${ }^{120}$ De facto, therefore, this last element of the rule of law value relating to the enforcement of legal norms is undoubtedly reflected in a satisfactory fashion onto the international plane, at least as regards the principal judicial organ of the UN system.

\section{CONCLUSION}

To summarise, the above discussion has shown that the formal core values of the rule of law are indeed reflected, to a large extent, in the essential features of the international legal system. One may even be tempted to speak of an emerging 'international rule of law', in terms of the externalisation of rule of law values. The strongest claim is at the level of normativity

117 GA Ajibola, 'Compliance with Judgments of the International Court of Justice' in MK Bulterman and M Kuijer (eds), Compliance with Judgments of International Court: Proceedings of the Symposium Organised in Honour of Professor Henry G Schermers by Mordenate College and the Department of International Public Law (The Hague: Martinus Nijhoff, 1996) p 9 at p 11.

118 See M Al-Qahtani, 'The Role of the International Court of Justice in the Enforcement of Its Judicial Decisions' (2002) 15 Leiden Journal of International Law 781.

$119 \mathrm{~K}$ Oellers-Frahm, 'Article 94 UN Charter' in A Zimmermann, C Tomuschat and K Oellers-Frahm (eds), The Statute of the International Court of Justice: A Commentary (Oxford: Oxford University Press, 2006) p 159 at p 175.

${ }^{120}$ See SM Schwebel, 'Commentary: Compliance with Judgments of the International Court of Justice,' in MK Bulterman and M Kuijer (eds), Compliance with Judgments of International Court:Proceedings of the Symposium Organised in Honour of Professor Henry G Schermers by Mordenate College and the Department of International Public Law (The Hague: Martinus Nijhoff, 1996) p 39 at p 40. 
per se, where nobody nowadays would doubt that the conduct of states is ruled by law, that is to say by legal norms providing for certainty, predictability and stability. The verdict as regards the functional dimension of the rule of law, concerning the creation and application of international law, is also relatively positive. International written legal norms found in treaties are promulgated satisfactorily and their publication is adequate; furthermore, international law is now universal in its reach and the fundamental principle of sovereign equality ensures that, in most cases (or with respect to most issues), similarly situated legal subjects (states) are treated in the same way; that is, without discrimination.

However, the institutional level remains problematic for the international rule of law, in spite of improvements in recent years. The continuing lack of compulsory jurisdiction for the International Court of Justice cannot be ignored, even if most states have committed to international adjudication through the optional clause. There is also a will to open the door to a power of judicial review for the ICJ, which could rule on the legality of the decisions of other UN organs, such as the Security Council. No one seriously contests the independence and impartiality of the International Court of Justice, and the judicial process is truly accessible to all states, the principal international legal subjects. In terms of effectiveness, the record of compliance is outstanding, but the Security Council's discretion over the ultimate enforcement of judgments still offends the international rule of law.

This picture of the situation of the rule of law on the international plane is, of course, flawed. I acknowledge that, in conducting the present analysis, many choices had to be made in order to limit the scope of the inquiry. For instance, treaties were the only source of normativity examined in regard to the first set of rule of law values, with adjustments made to take into account the absence of a central norm-creating authority on the international plane. Similar limits applied for the discussion of the creation of legal norms, where international customary law was neglected. The ideal of equality was assessed in relation to states only, although the modern trend is to recognise an international role for other legal actors, such as individuals. Finally, I looked only at the International Court of Justice to see whether the rule of law values relating to the existence of a judicial system were reflected onto the international plane. In truth, the present discussion on the international rule of law is not meant to be comprehensive. But it is a start. In fact, it is a serious effort to examine the situation of international law today, understood in traditional terms-with treaties as the main source, states as the principal actors, and the ICJ as the leading court.

By way of concluding remarks, it is opportune to bring back the theme of the social power of the 'rule of law,' that is of the 'international rule of law'. The great success of this social-mental phenomenon has been noted 
in both legal studies and political science. ${ }^{121}$ One may gain a sense of the popularity of the international rule of law language from the final document of the 2005 World Summit, where some 170 heads of state and government met for a high-level plenary meeting at the sixtieth session of the United Nations General Assembly. ${ }^{122}$ The expression 'rule of law' is found no less than 12 times, including in the first section on 'values and principles', as well as under the headings of development, human rights and investments. There is even a specific section on the rule of law, where the states recognise 'the need for universal adherence to and implementation of the rule of law at both the national and international level'. Furthermore, it advocates the creation of a Rule of Law Assistance Unit within the Secretariat, 'so as to strengthen United Nations activities to promote the rule of law, including through technical assistance and capacity-building'.

The language of the rule of law has fallen victim to its own success. ${ }^{123}$ In a sense, it has become the new 'buzzword' (or 'buzz-phrase') at both the domestic and the international level, in terms of which political and justice enterprises are examined and explained. ${ }^{124}$ The modern vernacular of political science (mainly international relations theorists) and of legal studies (mainly constitutional theorists) has also adopted the terminology of the rule of law with great enthusiasm, using it in relation to practically every aspect of the organising structure-system in society; ${ }^{125}$ from regional criminal justice, to national transitional justice, to transnational social justice; from domestic democratic reforms, to supranational institutional reforms, to international development reforms. I borrow from Ogden and Richard's philosophy of language to suggest that the 'rule of law' is a formulation of 'Hurrah!' words,'126 that is to say, words

121 See, for instance, D Jacobs, 'The Rule of International Law' (2006-07) 30 Harvard Journal of Law and Public Policy 15; and B Zangl, 'Is there an Emerging International Rule of Law?' (2005) 13 (suppl 1) European Review 73.

122 United Nations, World Summit Outcome, GA Res 60/1 (2005), available at www. un.org/summit2005/.

123 For a taste of the far-reaching success of the rule of law language, see BZ Tamanaha, 'The Rule of Law for Everyone?' (2002) 55 Current Legal Problems 97 at 98-100.

124 See K Samuels, 'Rule of Law Reform in Post-conflict Countries: Operational Initiatives and Lessons Learnt' (2006) World Bank Social Development Papers, Conflict Prevention $\mathcal{E}$ Reconstruction 2006/37.

125 See the different contributions to the present volume, as well as in D Dyzenhaus (ed), Recrafting the Rule of Law (Oxford: Hart Publishing, 1999). See also, at the purely domestic level, S Coyle, 'Positivism, Idealism and the Rule of Law' (2006) 26 Oxford Journal of Legal Studies 257; and DM Beatty, The Ultimate Rule of Law (Oxford, Oxford University Press, 2004).

126 See CK Ogden and IA Richards, The Meaning of Meaning: A Study of the Influence of Language upon Thought and of the Science of Symbolism, 2nd edn (London: Kegan Paul, 1927) pp 149-50, where the authors suggest dividing the functions that language can fulfil into two categories, namely the symbolic use of words and the emotive use of them. In the latter function, language is used to express or excite feelings and attitudes; the language thus used can be referred to as 'Hurrah!' words and 'Boo!' words, because of the feelings, good or bad, that they bring to the speakers and/or listeners. 
that provoke a positive effect—-that generate a good feeling in those who hear them.

Unfortunately, this is also true when the rule of law language is utilised by the Robert Mugabe and other tyrants of the world, ${ }^{127}$ or by economically aggressive state governments like that in Beijing. ${ }^{128}$ In short, there are reasons to be both happy and to be concerned about the externalisation of the concept, ${ }^{129}$ reasons to be simultaneously for and against the international rule of law. ${ }^{130}$

127 See statements reported in Tamanaha, n 123 above, pp 99-100.

128 See the Chinese Government's statement on the rule of law at the national and international levels, reported by Duan J in (2007) 6 Chinese Journal of International Law 185.

129 Every virtuous thing has a dark side, David Kennedy would say: see D Kennedy, The Dark Side of Virtue: Reassessing International Humanitarianism (Princeton, NJ: Princeton University Press, 2004).

${ }^{130}$ I owe this formulation to Brian Tamanaha, who expressed a similar view with respect to the rule of law in general during a discussion at the Florence conference. See more generally, his contribution to the present volume (ch 1). 
